\title{
Representations and Realization of Written Planning of PSE Teachers in Tunisia
}

\author{
Ben Chaifa Mounira ${ }^{1}$, Abd Elmajid Naceur ${ }^{2}, \&$ Elloumi Mohamed ${ }^{3}$ \\ ${ }^{1}$ Doctor in SPA didactics \& Educational Consultant, RU: ECOTIDI, Tunisia \\ ${ }^{2}$ Professor at ISEFC, RU: ECOTIDI, Tunisia \\ ${ }^{3}$ Lecturer at ISSEP.KS. Tunis, MCO-HD2, Tunisia \\ Correspondence: Ben Chaifa Mounira, Doctor in SPA didactics \& Educational Consultant, RU: ECOTIDI, Tunisia.
}

Received: November 28, 2021

doi:10.11114/ijsss.v10i1.5437

\author{
Accepted: December 27, 2021 \\ Available online: December 30, 2021 \\ URL: https://doi.org/10.11114/ijsss.v10i1.5437
}

\begin{abstract}
Planning is an act of anticipation carried out by the teacher during the pre-active phase to prioritize the pedagogical and didactic teaching approaches. On the other hand, in the teaching field, the teaching-learning situation is also complex to be identified by simple planning. In this study, we seek to explain the influence of gender and the seniority of physical education and sports (PSE) teachers on representations of written lesson planning and its management in the field. We collaborated with 20 PSE teachers and 10 trainee students in initial training in secondary schools. We filmed practical sessions and we carried out two types of interviews with the participants and we analyzed the content of the written plans of the participants in our experiment. Our results show that the professional seniority and the gender of the PSE teacher do not modulate the representations that are made of the written planning of the lesson. However, in practice, the teacher's representations of written planning are not always consistent with their realization on the ground. The difference between teachers' representations of the PSE teacher's written planning and their teaching practices is dependent on the professional seniority and gender of the acting person. The actions of the actor are shaped by the aspects inherent in the learning situation, the actions of the teacher are therefore contextualized.
\end{abstract}

Keywords: representation, achievements, gender of PE teacher, written planning

\section{Introduction}

Clark and Yinger (1987)define planning as decision-making in the selection, organization and serialization of phase (pre-active and post-active, for Tochon (1989) of teaching allowing the individual to anticipate and represent the future by making an inventory of the ends and the means to be able to set up a framework allowing it to guide its actions to come. Veysseyre (2007) explains that the written traces are not considered only as "preparatory scenarios" or a sort of "didactic backstage" in the interactive phase, but also, spontaneous professional acts. During his written planning, the teacher arranges sentences, words, instructions, diagrams, signs and numbers. The author insists on considering these planned statements as teaching actions similar to real fingerprints from a professional environment. In 2008, Veysserre called them a "witness document" since they preserve and conserve the discourse and thought of teachers. He goes so far as to say that "planning is teaching" (Veysseyre, 2008, p. 386). Several authors (Musial, Pradère, \& Tricot, 2012; Perrin \& Ria, 2008; Veysseyre, 2007, 2008) demonstrate the indisputable roles of planning in the prioritization and arrangement of didactic and pedagogical teaching approaches. For Musial et al. (2012) planning is "avoiding sailing on sight and being surprised by the storm" (Musial et al., 2012, p. 2). It is an effective preparation for the implementation of teaching. It is the "structuring" of the teaching activity (Perrin \& Ria, 2008). However, planning remains without any difficulty, Musial et al. (2012) consider that planning is "thinking about the future" so planning does not necessarily mean that everything will work as expected. Riff and Durand (1993) explain that the difficulty of planning can come from several sources, the nature of planning which is based on the basis of anticipation, so it is none other than prognoses forecasts. In the field of education, and mainly in physical education, the teaching-learning situation is also complex to be identified by simple planning, hence events are difficult to predict since it is necessary to deal with pupils and follow changes in learning, or from incomplete information that is made available to the teacher, or ultimately, objectives that are multiple and very general. Given the difficulties of developing good planning Altet (1993) recommends building "open preparations", which Tochon (1989) calls "flexible planning". According to Perrin and Ria 
(2008), planning which takes into account the indeterminate nature of educational situations, anticipates the consequences of unexpected changes in student activity and adapts to unforeseen events during the educational intervention (Tochon, 1989). These operations remain inaccessible for beginning teachers due to their lack of "hierarchy of their knowledge" (Tochon, 1993a, p. 128), unlike experienced teachers who replayed a "vast repertoire of treatment procedures indexed on types of problems(Tochon, 1993a, p. 128). For Perrin and Ria (2008), the plan allows beginners to devote themselves more to their class and to manage certain unforeseen events. By refusing to adapt to the reality of the class, the teacher "forces the real" to keep and execute his plan, "their classroom experience is anxiety-provoking when reality departs from their plan and more pleasant when it conforms to it" (Perrin \& Ria, 2008, p. 1). For these authors, it is judicious or even necessary to learn to manage the unexpected and adapt to the reality of the professional situation. Therefore, the main thing is not to learn to plan well but rather to learn to adapt and adjust and take stock during the professional act and to focus on the essential aspects of teaching situations. These authors insist on the particular role of planning, during the initial training of teachers, by working on actions that gradually turn into routines. Pelletier and Jutras (2008) and Visioli and Petiot (2015) consider improvisation to be "a creative action" and pleads for improvisation training or what Perrnoud (1999b) calls training to deal with the unexpected.

\section{Methodology}

Following this literature review, we asked ourselves the following questions: is there a gap between the representations that PSE teachers make of written planning and its implementation in the field? would this gap be shaped by the length of service and / or gender of the teacher? In this study, we seek to clarify the influence of the seniority and gender of PE teachers on the representations that are made of written lesson plans and their management in the field. To answer our questions, we collaborated with 30 participants, including 10 experienced teachers and 10 beginner teachers, and 10 trainee students in initial training in secondary schools. They are divided into 15 men and 15 women. The volunteering criterion was essential here and the participants were all informed in advance of the research framework and conditions. To make this study a reality, we used two investigative techniques: first, we videotaped the gymnastics sessions at the rate of one session per teacher. These sessions lasted an average of 55 minutes. The teachers' interventions were filmed in situ, using three digital cameras, one of which was placed on the teacher's head, but which allowed him complete freedom of movement, in order to collect all verbal communications and all the angles targeted by the teacher. A second camera is manipulated by the researcher who follows all the teacher's movements at a respectable distance, thus guaranteeing wide shots capturing all the teacher's interventions with his students. A third camera mounted on tripods, in a corner of the gymnasium, provides very wide framing shots, allowing the teacher and all students to be viewed continuously. Second, 2 types of interviews with each participant were recorded: before the session, a semi-structured interview is carried out with each teacher filmed, in order to collect, as a first step, the representations made by the teachers of the written planning of the PSE lessons and of the changes made along the way. Subsequently, self-confrontation interviews, which serve to document the actor's pre-reflexive experience (Theureau, 1992) and to mark the changes and deviations from the written planning of the lesson, were conducted. A laptop computer and a video projector allowed viewing and projection of the videotape of the recorded lesson. A tape recorder was used to record audio of the post-lesson interviews. The playback of the videotape is interrupted by the pause, advance, return functions at any time at the request of the teacher or on the part of the researcher. The latter is accompanied by the written lesson plan provided by the teacher before the practice of the session. The teacher is confronted, at all times, with his actions which he is invited, by semi-open questions and based on the video, to explain what he was doing, thought, took into account to act, perceived, felt, (Vermersch, 1994).

For the data processing we started with the transcriptions of the semi-structured interviews and the self-confrontation. We then transcribed the practical sessions in the form of a two-part table, for part 1 actions of the teacher and students and for part 2 verbatim of the teacher. In a second step, we submitted the verbatim recordings as well as the responses of the two interviews to the content analysis technique in the form of grids containing the statements and the achievements. In the last step, we subjected the collected data to statistical processing using the SPSS software where we applied the chi-square test and we also used the calculation of the percentages for well-defined data.

\section{Results analysis}

\section{Representations and implementation of the session plan according to the seniority of the PSE teacher}

We submitted the results obtained from the semi-structured interviews and the comparison of the written planning to the filmed practical sessions (the pedagogical and didactic regulations on the ground compared to the written plan), classified according to the seniority of the teacher, to the test of khi2. The results are set out in Table 1. 
Table 1. Distribution of representations and the realization of the written lesson planning according to the professional seniority of the PSE teacher

\begin{tabular}{|l|c|}
\hline \multicolumn{1}{|c|}{ Declarations / Achievements } & Pearson's chi-square \\
\hline Teacher representations of written plans of the PSE lesson according to professional seniority &, 329 \\
\hline Realization of plans written during practical PSE sessions according to professional seniority &, 005 \\
\hline Number of sightings & 30 \\
\hline
\end{tabular}

According to Table 1, at the level of declarations there is not a significant difference between the representations of PSE teachers according to their degrees of seniority regarding the written planning of the session. In practice, there is a significant difference concerning the pedagogical and didactic regulations effectively carried out in the field.

Table 2. Testimonies according to the seniority of the teacher

\begin{tabular}{|c|c|c|}
\hline \multicolumn{3}{|c|}{ Testimonies according to the teacher's seniority } \\
\hline & Declarations & Achievements \\
\hline Trainee & $\begin{array}{l}\text { Normally we have a programming that we did after a } \\
\text { competition session and therefore, we have to follow } \\
\text { the content of the sheet, but after we can model to } \\
\text { change a situation, } \\
\text { we can change if necessary we can choose a situation } \\
\text { that we believe is suitable for the level of students but } \\
\text { when we put it into practice it turns out to be either } \\
\text { easier or more difficult compared at the level of my } \\
\text { students there I have to change }\end{array}$ & $\begin{array}{l}\text { I worked with groups of level so everything is already } \\
\text { planned the sheet is prepared on bases, namely the level } \\
\text { of the class, the size and I prepared situations which are } \\
\text { adapted to the level of my students, as long as the } \\
\text { content of the form is adapted with the capacities of the } \\
\text { pupils I content to apply it, except for my session there } \\
\text { the pupils do not take the initiative to try the boys are } \\
\text { unruly and the girls are too weak }\end{array}$ \\
\hline $\begin{array}{l}\text { Beginner } \\
\text { teacher }\end{array}$ & $\begin{array}{l}\text { During each session, there is always a discrepancy } \\
\text { between the file and the reality on the ground. With all } \\
\text { the imagination we have in preparing the sheet, when } \\
\text { we arrive on the ground we still discover a gap } \\
\text { between theory and practice. For me the educational } \\
\text { file is a theoretical plan, the practical work allows us to } \\
\text { discover the true level of the students and planning can } \\
\text { be either difficult or easy compared to the students so it } \\
\text { is necessary to make an adaptation. }\end{array}$ & $\begin{array}{l}\text { I prepare a lesson adapted to the level of my students } \\
\text { and I take into consideration the material conditions the } \\
\text { infrastructure and the number of students that I have, so } \\
\text { I will not be forced to change except when unforeseen } \\
\text { situations arise like the two girls who come for the first } \\
\text { time today I added an "optional workshop" that's how I } \\
\text { called it in my own conscience I always prepare } \\
\text { emergency situations for such cases. }\end{array}$ \\
\hline $\begin{array}{l}\text { Experienced } \\
\text { teacher }\end{array}$ & $\begin{array}{l}\text { If I find flaws I have no problem going back in the } \\
\text { progress of the exercise. I always make improvisations } \\
\text { and changes according to the levels of the students, I } \\
\text { correct according to the request and the levels of my } \\
\text { audience. There are things that we discover on the spot } \\
\text { during the lesson even if we prepare our lesson } \\
\text { properly, there are things that emerge instantly because } \\
\text { the student is present in front of you and he moves and } \\
\text { we cannot prevent all of these reactions. }\end{array}$ & $\begin{array}{l}\text { I make changes, I give the student the most, the more } \\
\text { instructions, I change the situation, I don't know I have } \\
30 \text { years of work and almost all blunders I know them } \\
\text { by heart, look there, there are girls who regress instead } \\
\text { of progressing. These girls worked against the wall, I } \\
\text { look for the whip of the free leg, when we passed on } \\
\text { carpet, I found that the free leg neither well known nor } \\
\text { well sheathed, it is not yet programmed in their brain, } \\
\text { the student does not know his body, I came back again } \\
\text { to the primary stage there, work on the bench. }\end{array}$ \\
\hline
\end{tabular}

In a second step, we calculated the percentages of didactic regulations and adjustments made according to the professional length of the participants in the practical sessions. The results are shown schematically by the following histogram:

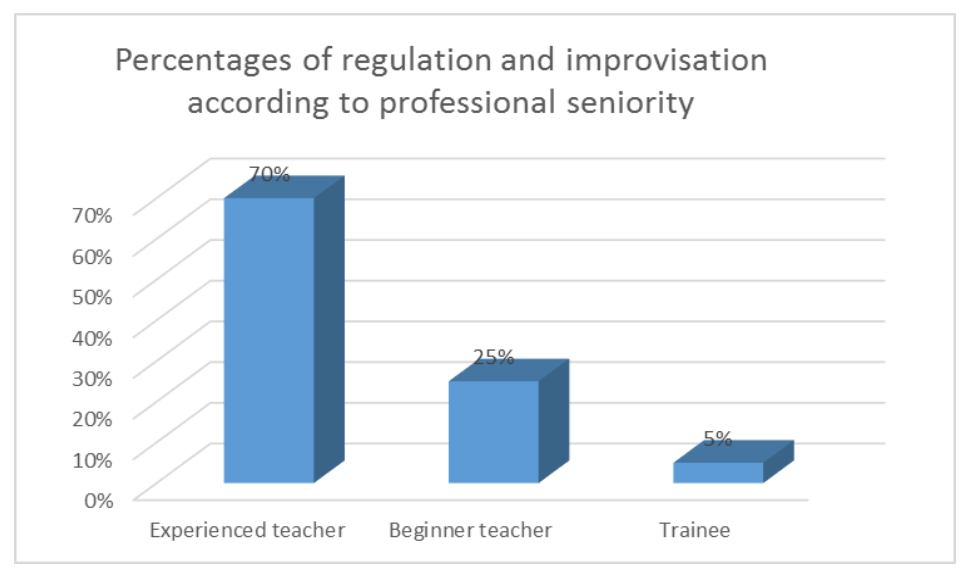

Histogram 1. percentages of didactic pedagogical regulations according to the seniority of the PSE teacher 
According to histogram 1 we notice the teachers participating in our study, including the student interns all carry out didactic regulations and adjustments thus modifying their original written planning. We also note that experienced teachers bring more didactic and pedagogical regulations, during their practical sessions, than novice teachers and student interns. Thus, the didactic and pedagogical regulations brought into class remain dependent on the professional seniority of the PSE teacher.

At the level of beliefs, both beginner and experienced teachers as well as student interns all agree that the written planning can be modified during the interactive phase and that the plan is just a lesson guideline.

An experienced teacher to declare "Concerning the regulations or the change, I believe that it is necessary, if the teacher theoretically foresees a very precise work as a consequence this work did not work or he felt that for the good success of the students it must change way or procedure or situation. There we discover the presence of the teacher. Normally we should not sit back or work on any educational situation." The experienced teacher speaks with certainty and self-confidence; his statements bear the imprint of professional experience which puts him in a comfortable position in the face of unforeseen events that arise along the way. He even affirms that the unforeseen are essential in the act of teaching to optimize the educational intervention.

A beginner teacher declares "I am not against change in general, in case we can make regulations, we can make modifications if the programmed content is not adapted to the level of the pupils, even of a few pupils only if not. I apply the content already prepared" The beginning teacher considers the teaching sheet as a theoretical plan which may at any time not coincide with the reality on the ground. The content can be modified according to the necessity of the practical moment so the teacher takes into consideration the aspects of the situation and the context of its unfolding.

a trainee student declared that "I am for adapting to real situations, for example if a situation does not work out and I can set up another situation which is not mentioned on the sheet then, I change much better than keeping a situation which does not work therefore, I intervene one is not obliged to apply the contents of the file if it cannot serve the students I am for the regulation and the remedied we had this information during our initial training and I personally have sometimes experienced it in the field." According to these declarations we note that the trainee students are also concerned by the didactic and pedagogical regulations they are already academically informed of this concept but they have also met it during their teaching practice therefore the trainee student faces the reality in the field and applies the theoretical content of the training during his pedagogical internship.

In practice, the experienced teacher, who remains the most faithful to his representations, makes changes and makes modifications without any hesitation. He takes into account the real working conditions and puts the success of the pupil in the foreground. he experienced uses solutions from an experiential repertoire that he has been able to develop over the years of work. An experienced teacher affirmed that "there are things that we discover on the spot during the lesson even if we properly prepare our session, there are things that emerge immediately because the student is present in front of you on material is also there so it's up to you to make the decision on the spot. You have to be creative and react instantly." According to the experienced teacher, the real situation requires the actors to adapt, thus creating a gap between theoretical preparation and its implementation on the ground. The teacher must act immediately to overcome obstacles and create an immediate solution, so the teacher's actions are contextualized and take place in situ. Theoretical planning can help the teacher but it does not orient his actions on the ground.

While the beginning teacher, even taking into consideration the material conditions, infrastructure and size of his students during planning, he is ready to change to face the reality of the classroom and he prepares situations of relaunch as a solution to pupils in difficulty. A beginning teacher argued as follows: "Yes, I have a certain gap in relation to the sheet because I found a situation that is not suited to the level of the students, yet I prepared the sheet properly there are unforeseen circumstances but this is a slight change in the conditions of realization, I just increased the distance of the swing for the pike jump but I did not touch the content." The beginning teacher despite trying to reduce the gap between theory and practice, by preparing a planning study well and taking into consideration all the conditions of the realization of the lesson, he adapt to the reality of the class and provide didactic and pedagogical regulations. There are even those who prepare alternate situations in case the planned situation does not work so that they do not waste time looking for a solution on the spot. So the experiential repertoire of the beginning teacher is not yet ready to deal with all the unforeseen events that may arise in situ.

On the other hand, the trainee student sticks to his planning and does not want to make any changes to it, since he thinks that he has prepared it on the basis, and he remits the failure to the student who lacks the will to work either out of indiscipline for the boys or because of the weakness of the physical strength of the girls. A trainee student mentioned "for this situation, at the beginning, I did not understand what is wrong because the sheet is prepared on the basis of the level of the class, the number of people and situations adapted to the level of the students., I felt but I don't see where the problem is and after I discovered it, frankly I hesitated to change it will disrupt the rest of the session, the change 
upsets the work and I don't know if it is the right solution or not I am afraid I will make a mistake and miss the session in addition, time is running out." The student intern does not quickly detect gaps and avoids changes along the way by fearing to miss his session. He cannot yet manage the time allocated to the session. In addition, he does not control the students who blames them for failure. An uncomfortable situation and feelings of hesitation and frustration for the student intern who finds it difficult to deal with a complex teaching situation made even worse with unforeseen circumstances arising from the current situation. As a result, he chooses to stick to his initial planning.

\section{Representations and implementation of the session plan according to the gender of the PSE teacher}

The results obtained from the semi-structured interviews were classified by gender and subjected to the Chi-square test to see if the teacher's gender impacts his statements about the theoretical preparation of the lesson:

Table 3. Distribution of the representations and the realization of the written lesson planning according to the gender of the PSE teacher

\begin{tabular}{|l|c|}
\hline \multicolumn{1}{|c|}{ Declarations / Achievements } & Pearson's chi-square \\
\hline Teacher representations of written PSE lesson plans by gender of teacher &, 068 \\
\hline $\begin{array}{l}\text { Realization of the plans written during the practical PSE sessions according to the gender of } \\
\text { teacher }\end{array}$ &, 008 \\
\hline Number of sightings & 30 \\
\hline
\end{tabular}

According to Table 3, there is no significant difference between the statements of male and female teachers about lesson planning. In practice, the difference is significant, to the detriment of the gender of the teacher, with regard to the pedagogical and didactic regulations actually carried out in the field.

Table 4. Testimonies by gender of teacher

\begin{tabular}{|l|l|l|}
\hline \multicolumn{2}{|c|}{ Testimonials by gender of teacher } \\
\hline Man & $\begin{array}{l}\text { Statements } \\
\text { For me the educational file is a theoretical plan, the } \\
\text { practical work allows us to discover the true level of the } \\
\text { students. Each session, there is a gap between the record } \\
\text { and the real on the ground so I always do improvisations } \\
\text { and changes. }\end{array}$ & $\begin{array}{l}\text { I noticed that there are two pupils in difficulty therefore } \\
\text { there it is necessary that my intervention is fast in the } \\
\text { positive direction, I added a workshop which is not } \\
\text { envisaged, to better facilitate their tasks, it is done in the } \\
\text { end they managed }\end{array}$ \\
\hline Women & $\begin{array}{l}\text { I come I have an educational sheet I want to reproduce it } \\
\text { exactly with the same situations that are noted. During the } \\
\text { session, we can model and evolve a situation, make } \\
\text { regulations, but basically it is the absence of the students } \\
\text { that push me to change }\end{array}$ & $\begin{array}{l}\text { There, I returned to an initial stage of the learning of the } \\
\text { Tense Reversed Support, these two girls are absent a lot, } \\
\text { they do not understand that the work in gymnastics is in } \\
\text { continuity there I find myself obliged, I do not like not } \\
\text { neglect the students even if they are absent. }\end{array}$ \\
\hline
\end{tabular}

In a second step we proceeded by calculating percentages: didactic regulations and adjustments made according to the gender of teacher during the practical sessions. We have submitted the didactic regulations and adjustments made, by all teachers including student interns, during the teaching practice, to the percentages. The results are shown schematically by the following histogram:

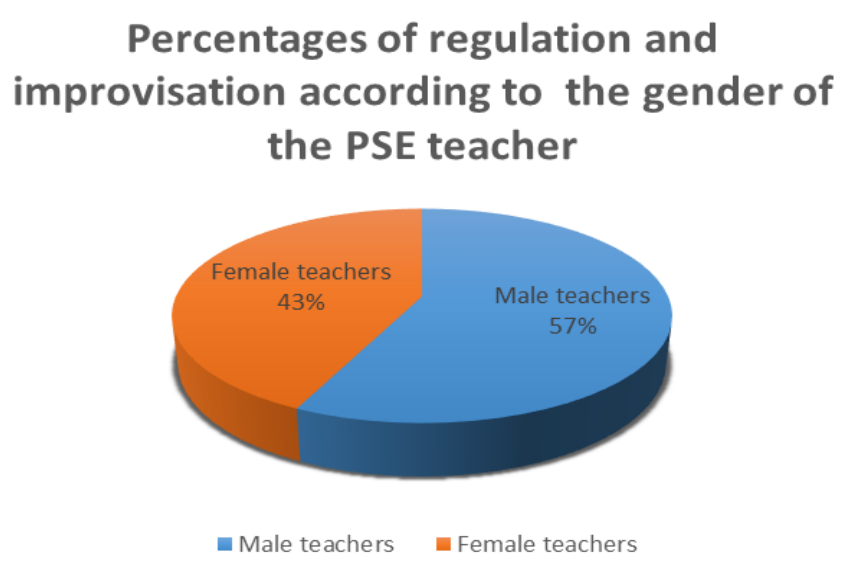

Histogram 2. percentages of didactic and pedagogical regulations according to the gender of the PSE teacher 
According to Histogram 2 We note that male teachers make more changes to their written plans than female teachers. Thus, the didactic and pedagogical regulations brought into class remain dependent on the gender of the PSE teacher.

At the level of beliefs of teachers, male and female, regulations and adjustments are possible during the interaction phase with students but for different reasons.

For male teachers it is a matter of experience and adaptation to the reality of the classroom or even the creativity of the teacher. A male teacher said, "Regulations are our daily life, we can't live without them, you just need to spot the loophole, you have to act instantly and fix it, it's an integral part of the teaching function."

On the other hand, for female teachers, adaptations of the content at the student level are necessary but above all, the origin of their changes are due to student absenteeism because the teachers think they plan their lessons meticulously. A female teacher mentioned "I will always be up to the individual and collective qualities of my students, I will always make an effort, I work according to the availability of the students, if I find flaws in the cognitive and practical levels of the students, I do not 'have no problem going back in the progress of the exercise or the progression of the sequence at the end of the cycle I want to see them on an equal footing even those who are absent, they have their reasons for sure, but me I fish them out."

In practice, male teachers are more flexible to changes along the way. A male teacher mentioned "I always improvise and change according to the levels of the students, I simplify or I add difficulties, I correct according to the demand and the levels of my audience". On the other hand, women remain more attached to their original plans; they only change when they feel compelled to do so. A woman justified her change as follows: "it is necessary to change according to the level of the students if a student has managed to master the requested gesture we should not keep him the same work so he will stagnate we can separate him and give him a job more difficult even if it is not planned on the form but in the case where the content works I do not change it. I take care of the details during the preparation of the worksheet. " women are more involved than men in the theoretical preparation of the lesson so they do not feel the need for change as long as everything is planned.

\section{Debate}

We have shown that there is a concordance in the representations of teachers according to their different degrees of professional seniority and their gender. So all the teachers arrive in class with a written plan and they are ready to modify it as long as it is not adapted to the levels of their pupils, while on the ground they show a different behavior. Our results show consistency with the previous work of several researchers who have worked on this concept. Nault and Fijalkow (1999) find it difficult to move from "idealistic representation" to daily practice. For Boizumault and Cogérino (2012), contradictions appear in the remarks on initial beliefs when teachers see themselves in action confronted with the video of practical session. Despite all the preparations for the pre-active phase of teaching Perrnoud (1999b) doubt the possibility of reducing the unexpected by planning in the face of a profession where we deal with human beings and he writes the unexpected in the very structure of the teacher's profession. Several authors (Altet, 1994a; Dessus, 2002; Dessus \& Schneider, 2006; Riff \& Durand, 1993; Tochon, 1989, 1993a, 1993b; Vinatier \& Altet, 2008), demonstrate that the teacher must adapt to the reality of the class and leads changes and makes adjustments to the activity initially planned according to unforeseen events occurring in class. Consequently, in practice, our results show that teachers, according to their different degrees of seniority and their gender, show different gaps between their original planning and their achievements in the field. According to our results, the student intern sticks to his planning and does not want to make changes to it and he hands the student back the failure, which coincides with the work of Perrin and Ria (2008), who claim that planning, often "obnubile", student interns, to the point, that they forget to follow the students' activity. As a remedy Perrin \& Ria encourage to identify and interpret the deviations from the planning instead of "sticking" to it, explaining that, the deviation from the planning makes it possible to focus the attention of the student trainee or the novice teacher on the essential aspects of teaching situations. We have also shown that the beginner teacher is ready for changes to face the reality of the class and prepares stimulus situations as a solution for students with difficulties. These remarks are, moreover, congruent with those of Dessus (1995a), which considers that the plan allows the beginner to devote himself more to his class and to manage certain unforeseen events. For Perrin and Ria (2008), the lesson plan can serve to limit the uncertainty of classroom interaction and the same time reduce the anxiety of the beginning teacher and lower his mental load. In addition, several authors (Alain, 2015; Pelletier \& Jutras, 2008; Tochon, 1993b; Visioli \& Petiot, 2015) defend the idea that the unexpected is a problem for beginning teachers since they do not have an experiential repertoire for to face, whereas (Azéma \& Leblanc, 2011, 2013), unlike the classical conception, conceive of improvisation as a "ceaseless creation of oneself", and that you don't necessarily have to be experienced to improvise but rather "improvise to become and remain an expert"(Azéma \& Leblanc, 2013, p. 4). this conception is adopted by our beginner teachers who prepare recovery situations as a solution for students in difficulty to replace the absence of the "experiential repertoire". According to our results, the experienced teacher makes 
changes and makes modifications without hesitation. He uses solutions from an experiential repertoire that he was able to develop over the years of work. These results agree with several previous researches (Perrin \& Ria, 2008; Riff \& Durand, 1993; Tochon, 1989) consolidate the important role played by routines in the planning activity of experienced teachers. Yildirim (2003) shows that personal work experience is one of the main factors influencing planning. During his planning activity, the experienced teacher focuses on the learning contents (Yildirim, 2003), and he can select from a directory of plans,(Riff \& Durand, 1993), progressively internalized in the form of routines. From a gender perspective of the teacher, our results show that, women remain more tied to their written plans and they only change when they are really obliged to do so since they think that they plan their lessons meticulously. On the other hand, men are more flexible to change and make more use of improvisation on the ground. Our results corroborate the results of previous research by Kneer (1986) who states that female teachers invest more time in planning than teachers.

\section{Conclusion}

The results obtained are modulated here by two major variables; declared and realized. Each of these major variables are broken down according to the length of service and gender of the teacher. At the level of beliefs, there is a concordance at the level of representations made by teachers of written planning according to their different degrees of professional seniority and their gender. The participants of this research place the importance of theoretical lesson planning, preparation during the pre-active phase of the session is necessary. They also all agree to make changes to the initial planning and adapt to the challenges of the practice session. In practice, they provide pedagogical and didactic regulations which are shaped by the seniority and gender of the teacher.

The experienced teacher is in a comfortable situation in his teaching practice, he faces the unexpected and he adapts to the reality on the ground. He uses solutions from an experiential repertoire. While the beginning teacher is not yet ready to deal with all the unforeseen events that may arise in situ. The student intern is hesitant to deal with unforeseen circumstances arising from the current situation. Men are more daring to didactic and pedagogical regulations, in the field, than women. On the other hand, they invest more during their written preparation to better identify the unforeseen.

The didactic and pedagogical regulations, made along the way, show that the plan guides the action of the teacher, but it does not induce it. Theoretical preparation of the pre-active phase cannot identify all the unforeseen events of the active phase. In practice, the facilitator must adapt to the reality of the classroom and adjust to the challenges of the teaching-learning situation.

Academic training is important to build representations in the teacher, but it is not enough to put them into practice. The actions of the actor are shaped by the aspects inherent in the learning situation, they are linked to the context of their unfolding. Everything is played out in class and in situ. Professional experience narrows the gap between the teacher's representations and their concretizations by gradually developing an experiential repertoire.

\section{References}

Alain, J. (2015). Face à l'imprévu: formation, improvisation ou bricolage? Cahiers pédagogiques, 477.

Altet, M. (1993). Styles d'enseignement, styles pédagogiques. In J. Haussaye (Ed.), la pédagogie: Une encyclopédie pour aujourd'hui. Pris: ESF.

Altet, M. (1994a). La formation professionnelle des enseignant Paris: P. U. F.

Azéma, G., \& Leblanc, S. (2011). L'improvisation, objet paradoxal et praxis incontournable du travail ordinairede l'enseignant. Paper presented at the le travail enseignant au XXIe siècleperspctives croisées: didactiques et didactique professionnelle, UFM de l'academie de Montpellier.

Azéma, G., \& Leblanc, S. (2013). L'improvisation en enseignement, un chèque avec ou sans provision. Paper presented at the actualité de la recherche en Education et en Formation Montpellier.

Boizumault, M. B., \& Cogérino, G. (2012). La mise en scéne corporelle de l'enseignat d'EPS: les communications non verbales aux service de l'efficacité de l'enseignant STAPS, 98, 67-79. https://doi.org/10.3917/sta.098.0067

Clark, C. M., \& Yinger, R. J. (1987). Teacher planning. In J. Calderhead (Ed.), exploring teachers'thinking (pp. 84-103). Londres: cassel.

Dessus, P. (1995a). Effets de l'expérience et de la matière dans l'utilisation de routines pour la planification de séquences d'enseignement. Cahiers Recherche et Education, 2(3), 1-28. https://doi.org/10.7202/1018201ar

Dessus, P. (2002). Les effets de la planification sur l'activité de l'enseignant en classe In P. Bressoux (Ed.), Les stratégies de l'enseignant en situation d'interaction (pp. 19-33). Grenoble France: Université Pierre-Mendès.

Dessus, P., \& Schneider, D. K. (2006). Scénarisation de l'enseignement et contraintes de la situation. Paper presented at 
the scénariser l'enseignement et l'apprentissage: une nouvelle compétence pour le praticien, Lyon.

Kneer, M. (1986). Descriptions of physical education instructional theory: practice gap in the secondary schools. Journal of Teaching in Physical Education, 2, 91-106. https://doi.org/10.1123/jtpe.5.2.91

Musial, M., Pradère, F., \& Tricot, A. (2012). Comment planifier mon enseignement. In M. Musial, F. Pradère \& A. Tricot (Eds.), Comment concevoir un enseigment? Bruxelles: Deboeck.

Nault, T., \& Fijalkow, J. (1999). Introduction. la gestion de la classe: d'hier à demain. Revue des sciences de l'éducation, 25(3), 451-466. https://doi.org/10.7202/032009ar

Pelletier, J. P., \& Jutras, F. (2008). Les composantes de l'entrainement à l'improvisation actives dans la gestion des imprévus en salle de classe du niveau secondaire. Revue des sciences de l'éducation de Mc Gill, 43(2), 187-212. https://doi.org/10.7202/019582ar

Perrin, N., \& Ria, L. (2008). Qu'est ce qu'une bonne planification pour enseignant (... en formation)? Retrieved from https:/hal.archives-ouvertes.fr/hal-00803969

Perrnoud, P. (1999b). Gestion de l'imprévu, analyse de l'action et construction de compétences. Education Permanente, $140(3), 123-144$.

Riff, J., \& Durand, M. (1993). Planification et décision chez les enseignants bilan à partir des études en EPS, analyses et perspectives. Revue Française de pédagogie, 103, 81-107. https://doi.org/10.3406/rfp.1993.1299

Theureau, J. (1992). Le cours d'action: analyse sémiologique. Berne: Peter Lang.

Tochon, F. V. (1989). Aquoi pensent les enseignants quand ils planifient leurs cours? Revue Française de pédagogie, 86, 23-33. https://doi.org/10.3406/rfp.1989.1425

Tochon, F. V. (1993a). L'enseignant expert. Paris: Nathan.

Tochon, F. V. (1993b). Le fonctiooement "improvisationnel" de l'enseignant expert Revue de sciences de l'éducation 193, 437-461. https://doi.org/10.7202/031641ar

Vermersch, P. (1994). L'entretien d'explicitation. Paris: ESF.

Veysseyre, P. (2007). Les traces écrites de planification en EPS, espace de médiation entre l'expérience de l'enseignement et l'action d'enseignement le cas de handball. Paper presented at the colloque Clemont-Ferrand.

Veysseyre, P. (2008). Les traces écrites de planification en EPS, espace de médiation entre les savoirs experts et l'action d'enseignement, le cas de handball. Université Lumière, Lyon 2.

Vinatier, I., \& Altet, M. (2008). Introduction: les analyses de la pratique et de l'activité de l'enseignant In I. Vinatier \& m. Altet (Eds.), Analyser et comprendre la pratique enseignante Presses universitaire de Rennes. https://doi.org/10.4000/rechercheformation.981

Visioli, J., \& Petiot, O. (2015). Dynamique de l'improvisation dans l'activité d'un enseignant en cours d'EPS: quelles relations avec les émotions et la spécialisation dans l'APSAenseignée. eJRIEPS, 36, 35-70. https://doi.org/10.4000/ejrieps. 1420

Yildirim, A. (2003). Instructional planning in a centralized school system: lessons of a study among primaryschool teachers in Turkey. International review of education, 49(5), 525-543.

\section{Copyrights}

Copyright for this article is retained by the author(s), with first publication rights granted to the journal.

This is an open-access article distributed under the terms and conditions of the Creative Commons Attribution license which permits unrestricted use, distribution, and reproduction in any medium, provided the original work is properly cited. 